\title{
Sibyl Moholy-Nagy: Architecture, Modernism and Its Discontents
}

Book Review / THEORY

Eszter Polonyi

\author{
Sibyl Moholy-Nagy: \\ Architecture, Modernism \\ and Its Discontents \\ By Hilde Heynen \\ London: Bloomsbury \\ Studies in Modern Architecture, 2019 \\ $234 \mathrm{~mm} \times 156 \mathrm{~mm}$ \\ 288 pages \\ US\$100.00 (hardback), \\ US\$ 31.46 (paperback) \\ ISBN: 978-1-350094-11-6
}

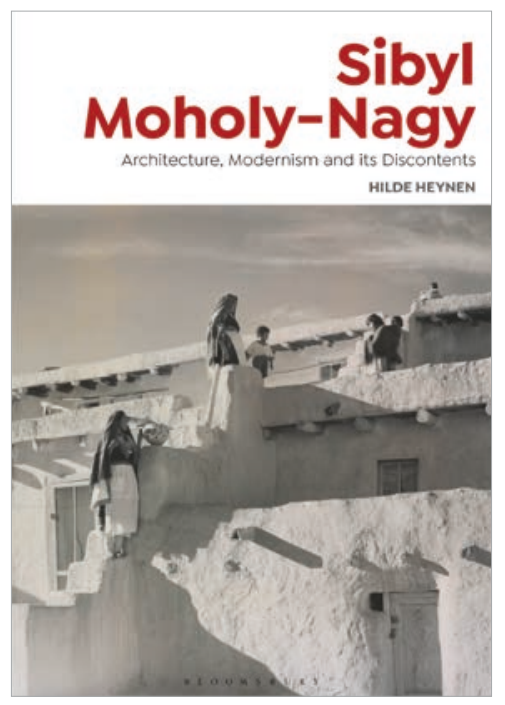

In a 1961 article dedicated to the state of the architectural curriculum entitled "The Future of the Past," the German historian, critic, and educator Sibyl Moholy-Nagy placed a photograph of an interior court of an embassy designed in 1959 in juxtaposition with one of a factory interior from 1920 and that of a twelfth-century cathedral. Certain commonalities in structure become apparent when the images are viewed side by side. These interior quads appear amid the walls that rise three to four stories overhead, creating a funnel-shaped space that would be confining, had the architect not punctured its top and thereby turned the space into a single shaft of light. Sibyl Moholy-Nagy shows the recurrence of this massive light vessel in buildings remote from each other in purpose, culture, and time to make 
a point. Form for her is not always "controlled" by the use for which it was intended, nor is it erected for the sake of technical virtuosity; instead, it can also be the result of historical awareness, an elective affinity between two eras of architecture. Here and elsewhere in the writings she produced, Moholy-Nagy judged the merits of a building based on the perspective it offered through the historical past and the constellation of references it brought to mind. For her, architecture was "not the static result but the intentional process," a process of thinking through matter and form.

Sibyl Moholy-Nagy, who was born in 1903, accomplished widespread recognition by the time of her passing in 1971. Among the generation of intellectuals who fled Central Europe in the 1930s, Moholy-Nagy taught and lectured at institutions across the United States and back in Europe, stopping at thirteen different German universities on one particular lecture tour. In the US, she received a range of honors, including an Arnold W. Brunner Grant from the Architectural League (1953), a Guggenheim Fellowship (1967), and the American Institute's "Critic of the Year" award (1970). She wrote approximately two hundred articles, placing many in the College Art Journal and in Progressive Architecture. During the two decades of her career, she published books on a range of topics including architecture, the urban environment, modernist art, and pedagogy, several of which received acclaim, most notably Native Genius in Anonymous Architecture (1957) and Matrix of Man: An Illustrated History of Urban Environment (1968). She was the first woman faculty member to achieve tenure at the Pratt Institute. And yet, Hilde Heynen's Sibyl Moholy-Nagy: Architecture, Modernism and Its Discontents (2019), the first of Janina Gosseye's and Tom Avermaete's new series "Bloomsbury Studies in Modern Architecture," is also the first book on Sibyl Moholy-Nagy. MoholyNagy faded into complete obscurity after 1971, at Pratt - despite the inauguration of an endowed faculty position in her name - and elsewhere.

And while Moholy-Nagy is neither the first nor the last established female author to vanish from the collective pool of scholarly references after her death, it is worth considering both her work and its reception for reasons why this happened. Until Heynen's book, the opinion of her readers and former colleagues had been fairly unanimous. Virtually infallibly, her marginalization was blamed on the difficulty of her personality: she was called "controversial," "rude," "dominant," "cantankerous," "volatile," etc. There is ample evidence that Moholy-Nagy dispensed criticism unsparingly. She appears to have been outspoken with architects, scholars, editors, and colleagues regardless of whether she considered them allies, competitors, or enemies. While during her lifetime, Moholy-Nagy's reputation for combativeness may have preceded her, with fifty years of hindsight, this should no longer be the case (not to mention that the "nasty woman" label places Moholy-Nagy in rather fine company as far as scholars go). Which is all to say that it is high time for a book like Heynen's. 
Heynen's book offers refreshing insight into Moholy-Nagy's overall project. Assembling articles, reviews, lecture notes, books, and correspondence from several archives, including at the University of California Santa Cruz (USCS), the Walter Gropius papers collection, and the Smithsonian, Heynen groups Moholy-Nagy's work into six chapters. The first is dedicated to her biography, the last to her legacy, and the remaining four chapters piece her writing together around the topics of "Vernacular Architecture and Uses of the Past," "Modernism and the Forces of History," and "The Great City and Its Civic Culture," and "Teaching as Vocation," thereby not only surveying the range of her writing but undertaking the delicate task of constituting it into an oeuvre. The Moholy-Nagy who emerges from these pages had the poise and humility necessary to teach herself architectural history, criticism and theory and to identify what she was best suited to bring to the field. In Heynen's deft rendering, her contributions appear firmly in dialogue with the emerging postwar academic architectural discourse. The chapter "Teaching as Vocation" places Moholy-Nagy within the postwar emergence of architectural history and theory as an academic field of research independent from the concerns of practice, an effort that her work helped initiate, but also one in which she was ultimately sidelined. Reconstructing Moholy-Nagy's role in several disciplinary debates, notably the MAS symposium at Columbia University in 1962 and the Cranbrook Academy of Art seminar in 1964, Heynen shows that her aspirations for what might today be called research-based practice was at odds with the concern for academic training that typically characterized the doctoral programs that were soon to be launched in architecture. ${ }^{1}$ Heynen writes, "Moholy-Nagy [...] positioned herself also in this context as first of all a teacher of the next generation of architects. Her work in architectural history was not for the sake of history, but for the sake of architecture." 2 An astute differentiation on Heynen's part, this point regarding MoholyNagy's commitment to pedagogy nonetheless could bear closer analysis, particularly as issues of methodology figure centrally in her critical reception.

The concept of history is among the topics Heynen focuses on in her treatment of Moholy-Nagy's research. Moholy-Nagy's 1968 book Matrix of Man receives the most extensive treatment in this respect. Heynen suggests that the decision-making behind the topic of the book was particularly politic. In "The Great City and Its Civic Culture," she places the book within a growing interest in the historic city during the 1960s. Her focus on architecture is contrasted with the more speculative methods of Lewis Mumford, whose 1961 The City in History approaches the urban fabric as a total environment. And while Moholy-Nagy makes a point of illustrating specific structures to avoid Mumford's vague "moralizing," her ambition appears to be no less to convey that "it is the ethical obligation of the architect-planner to be totally responsible for the physical matrix of society." " ${ }^{3}$ Cities, for both Moholy-Nagy and Mumford, were "matrices" in the sense of a cast or mold that generated human subjectivity. If Moholy-Nagy 
provided extensive illustrations in contrast to Mumford, it was because she wanted to make this crucible of experience visible to her reader. Heynen is correct in noting the tension in her work between empirical micro-analysis and broad temporal breadth, with comparisons that operate across several millennia's remove potentially appearing facile to the trained historian.

Another reading of her work might relate this methodology with the logics of visual comparison underpinning the Bauhaus books, of which Moholy-Nagy retained lifelong (if shared) copyright.

Heynen's treatment of Sibyl Moholy-Nagy is firmly embedded in architectural discourse. The advantage is assessing Moholy-Nagy's writing in the disciplinary terms with which she officially identified. Recovery of her success in this field also makes it an appropriate study in the new series by Bloomsbury Press, of which the book appears as among the first. But the interdisciplinary viewpoint is particularly necessary in the case of MoholyNagy, who not only officially bore the title of art history professor, but who was also clearly versed in the historiography of art history, as evidenced by her publication of a translation of the painter Paul Klee's notebooks, ${ }^{4}$ a study of European folk art, ${ }^{5}$ and a monograph on László Moholy-Nagy, ${ }^{6}$ the latter is without question her most widely read work. Herself a critic of static traditions, Moholy-Nagy offers ample occasion to cross-hybridize histories of art, architecture, and, given her production of several exquisitely illustrated volumes, potentially book media as well.

The most conspicuous casualty in Heynen's account of the cast of close Sibyl Moholy-Nagy intellectual associates is her husband and namesake László Moholy-Nagy. There might be good reasons for this. In principle, Heynen underscores Sibyl's independence from László by reducing reference to him to three to four chapter sub-sections. Née Sibylle Pietzsch (she adopted the anglicized Sibyl in 1924), Moholy-Nagy met the Hungarian-born light designer and educator in Berlin in 1931. Marrying in 1935 and bearing him two daughters (Hattula, b.1933 and Claudia, b. 1936), the two decades Sibyl passed by his side involved his celebrated efforts to bring the pedagogic innovations of the Bauhaus to North America. Sibyl's commitment to pedagogy must be read within this context, something that is implied by the appearance of Heynen's book on the year of the Bauhaus centennial and alongside a range of studies that recover women associated with the school (for instance by Laura Framm, Elizabeth Otto, and Patrick Rössler). Although the version of the Bauhaus represented by Sibyl Moholy-Nagy comes after its dissolution on German soil in 1933, she remains within its conceptual orbit. Tellingly, two documentaries on the Bauhaus produced in 2019 feature Sibyl prominently, a well-researched study of László's American pursuits, ${ }^{7}$ and a re-enactment of Sibyl's and László's meeting and relationship. ${ }^{8}$

László is not Sibyl's sole connection to the Bauhaus. It is true that their involvement in each other's lives likely gained Sibyl the preparation 
necessary to begin teaching and researching without a doctoral degree (see particularly "Moholy's Intellectual Legacy"). Moreover, managing his estate and legacy would constitute her first project, as evidenced by Experiments in Totality (1950) and the posthumous publication of Vision in Motion (1947). But looking beyond László, one readily comes across the names of Walter Gropius, Ise Gropius, Marcel Breuer, Lucia Moholy, György Kepes, and Siegfried Giedion, all of whom arguably had a hand to play in her career, for instance with the first and last figuring as reference providers on her tenure documents at Pratt. As the architect Lee Cott notes in Heynen's book, "We were always told [...] that Gropius came to Harvard, Mies came to Chicago, and Sibyl came to Pratt." " Sibyl both acted on her Bauhaus connections and continued to be associated with them, whether or not it served her aims.

The final reason it might be productive to extend Heynen's research in a closer examination of Moholy-Nagy's relationship to the Bauhaus is her apparent dismissal of mechanized production. In Heynen's chapter "Modernism and the Forces of History," Moholy-Nagy is shown to feel threatened by the rationalized methods embraced by modernists like Mies van der Rohe and Marcel Breuer in the postwar period, whose application of standardized and modular systems that she believed anathema to a balanced and respectful relationship to the environment. According to this logic, her study of North American settler architecture in Native Genius in Anonymous Architecture could be read as celebrating preindustrial methods of construction. However, this is unlikely, if only because of the two decades she spent with László Moholy-Nagy, a technophile avant la lettre. It is more likely to be because rather than in spite of the rapidly developing relationship of post-war designers to technology that Moholy-Nagy initially chose architectural history over art history - a field of study with much less obvious connection to mechanical media. As Heynen herself suggests in her chapter, "Vernacular Architecture and Uses of the Past," MoholyNagy discerned in the surfaces of anonymous architecture a discriminatory judgment, appreciation of chance, and a combinatory historical imaginary that appeared to solve planning problems through embodied methods. Like the student, the anonymous architect has an intuitive capacity for problemsolving that stemmed from a presumed lack of professional training, an appreciation of chance, and a combinatory imagery. In other words, the anonymous architect had acted similarly to an imagined architecture machine, with the difference being their possession of historical knowledge. 


\section{Notes}

1. Hilde Heynen, Sibyl Moholy-Nagy: Architecture, Modernism and lts Discontents (London: Bloomsbury, 2019), 174-90.

2. Ibid., 186.

3. Ibid., 159.

4. Paul Klee, Pedagogical Sketchbook, trans. Sibyl Moholy-Nagy (London: Faber, 1968).

5. Helmuth Theodor Bossert, Folk art of Europe (New York: Praeger, 1953).

6. Sibyl Moholy-Nagy, Experiment in Totality (1950; repr. Cambridge MA, USA: MIT Press, 1969).

7. Alysa Nahmias, director of the film The New Bauhaus, 2019.

8. Angela Zumpe, director of the film Things to Come, 2019.

9. Heynen, 208.

Eszter M Polonyi is a Visiting Assistant Professor at the History of Art and Design department of Pratt Institute. Her research investigates the effects of industrial media on the art, films, literature and thought of twentieth-century Central and Eastern Europeans. Her work has appeared in Apertura, Found Footage Magazine, The New Review for Film and Television, and in edited collections dedicated to the legacies of leftist intellectual traditions. She has been supported by the Mellon, Pepsico, DAAD, SSRC DPDF and other cultural foundations. E-mail: epolonyi@pratt.edu 